\title{
CLIMATE IMPACT ON AGRICULTURE SECTOR IN INDIA
}

\author{
Jadhav K. B. * and Lohar D. N. \\ Shrimant Babasaheb Deshmukh Mahavidyalaya, Atpadi Dist:- Sangli (MS) \\ *Corresponding Author: kbjadhav2012@,rediffmail.com
}

Communicated: 10.07 .2020

Revision : $13.07 .2020 \&$

4.08 .2020

Accepted: 20.08 .2020
30.09.2020

\begin{abstract}
Agriculture is important in India for the obvious reasons of its Central centrality given that it accounts for a large share in GDP and larger share in in employment. It shows that climate change could reduce farm income by $16 \%$ and by $22 \%$ in unirrigated areas. Maharashtra as one of the most valuable states in the country social and technological indicators. The state has low 'adaptive capacity' to climate change. Additionally, studied by Central Research Institute for Dry land Farming says 'District in Maharashtra and Vidarbha face very high risk to climate change and if no action to take financial implications on account of damages due to climate change wood massive' Mumbai alone can incur financial damages of as much as Rs. 2 trillion due to climate change related damages. Agriculture sector in India is vulnerable to climate change higher temperature to reduce crop yield and fever weed and paste proliferation. Government of India has initiated various actions to mitigate effects of climate change. Varieties and Cultivators tolerant two abiotic stress and developed under strategic research component of N I C R A district agriculture contingency plan have been prepared by I.C.A.R. C.R.I.D.A Hyderabad for 648 districts in the country to address the adverse weather conditions. At least $80 \%$ of the total area under agriculture cultivation is rain fed in the state out of the total 355 Talukas in the state, 122 Taluka received normal rainfall and 226 received deficient rainfall. Only 17 Talukas received excess rainfall. Agriculture is an important sector of Indian economy. Agriculture and fisheries are highly dependent on climate. Increases the temperature and carbon dioxide can increase some crop yields in some places but to realize these benefits. Overall climate change could make it more difficult to grow crops raise, animals and catch fish in the same ways and some places as we have done in the past. We also find that there has been a steady increase in temperature extremities. The number to vary not days as well as the number of dry days has increased, constant with models of climate change which predict increased variability in weather.
\end{abstract}

\section{INTRODUCTION:}

Agriculture is important in India for the obvious reasons of its Central centrality given that it accounts for a large share in GDP and larger share in in employment. It shows that climate change could reduce farm income by $16 \%$ and by $22 \%$ in unirrigated areas. Maharashtra as one of the most valuable states in the country social and technological indicators. The state has low 'adaptive capacity' to climate change. Additionally, studied by Central Research Institute for Dry land Farming says 'District in Maharashtra and Vidarbha face very high risk to climate change and if no action to take financial implications on account of damages due to climate change wood massive' Mumbai alone can incur financial damages of as much as RS 2 trillion due to climate change related damages. Agriculture sector in India is vulnerable to climate change higher temperature to reduce crop yield and fever weed and paste proliferation. Government of India has initiated various actions to mitigate effects of climate change. Varieties and Cultivators tolerant two abiotic stress and developed under strategic research component of N I C R A district agriculture contingency plan have been prepared by I.C.A.R. and C.R.I.D.A Hyderabad for 648 districts in the country to address the the adverse weather conditions. At least $80 \%$ of the total area 
under agriculture cultivation is rain fed in the state out of the total 355 Talukas in the state, 122 Taluka received normal rainfall and 226 received deficient rainfall. Only 17 Talukas received excess rainfall. Agriculture is an important sector of Indian economy. Agriculture and fisheries are highly dependent on climate. Increases the temperature and carbon dioxide can increase some crop yields in some places but to realize these benefits. Overall climate change could make it more difficult to grow crops raise, animals and catch fish in the same ways and some places as we have done in the past. We also find that there has been a steady increase in temperature extremities. The number to vary not days as well as the number of dry days has increased, constant with models of climate change which predict increased variability in weather.

\section{Objective of the study:}

1. To study Indian agriculture sector.

2. To understand the long run impact of Climate Change in India.

3. To examine the impact of rainfall.

4. To study how climate change affects the agriculture sector in India.

5. To study how climate affects the economic conditions of farmer in India.

\section{Impact on crops:}

Crops grown in the India are critical for the food supply here and around the world change in the temperature and intensity of extreme weather would have significant impact on crop yields. More extreme temperature and precipitation can prevent crops from growing. Extreme events especially floods and a drought, can harm crops and reduce the yield.

\section{Impacts on livestock:}

Heat stress affects animals both directly and indirectly, heat stress can increase vulnerability to diseases, reduced fertility and reduce milk production. Climate change may be lincreasing the prevalence of parasites and diseases that affect livestock.

\section{Impacts on fisheries:}

Changes in temperature can affect the timing of reproduction and migration.

\section{CONCLUSION}

1. Climate change is a very likely to affect food security at the Indian.

2. Climate change can disrupt food availability, reduced access to food and affect food quality.

3. Any climate related disturbance to food distribution and transport may have significant impact not only on safety and quality but also on food access.

4. Impact to the Indian food supply concern because food shortage can cause humanitarian crisis and national security concern.

5. They also increase domestic food prices.

6. India being preliminary and Agriculture economic face the threat of climate change to major extinct.

7. It is more so in India as our economy is more dependent on agriculture.

\section{POLICY IMPLICATION}

1. There is an urgent need to spread irrigation

2. Research in agriculture Technology needs to be stepped up in order to develop crop varieties and cropping techniques which are resilient to the vagaries of weather.

\section{REFERENCES:}

Government of India report (2018) - Economic Survey of India 2018-19

Pathak H., P.K. Agarwal and S.D. Singh 2009

Climate change impact adaptation and mitigation in agriculture methodology for assessment and applications

Indian Agricultural Research Institute, New Delhi 
Subramanyam A. (2017) Transforming Indian agriculture by loving some agriculture less and rest more

Lecture at National Academy of Agricultural Science.
Singh H. S. Potential impact climate change on mangroves in India (0894 - B2)

Document on National Action Plan on climate change India 